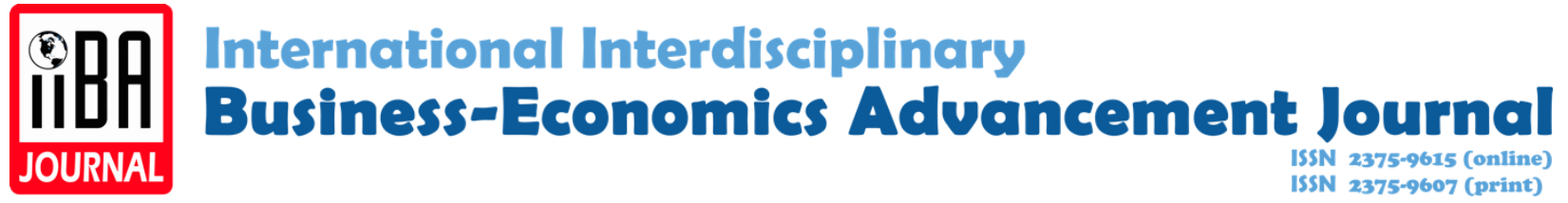

\title{
Furthering the debate on globalization's origins: New evidence
}

P. Edward Leffler

King's College London

\section{Recommended Citation}

Leffler, P. E. (2016). Furthering the debate on globalization's origins: New evidence. International

Interdisciplinary Business-Economics Advancement Journal, 1(1), 11-18. 


\title{
Furthering the Debate on Globalization's Origins: New Evidence
}

\author{
P. Edward Leffler \\ Department of European and International Studies \\ King's College London \\ edwardleffler1@gmail.com
}

\begin{abstract}
Throughout recorded human history there have been small shifts in how humans have interacted with each other. The ancient empires of the Far East, Near East, and Europe emerged from the city and city-states, tribe and communities began to trade with each other, written language allowed for the transference of knowledge between cultures and across the span of time. Of these monumental shifts there have been few. The most recent of these event thresholds is Globalization. Globalization is here, for our benefit or loss, and has begun to affect every part of our society: from the goods we consume, to the money we use, to the music we listen to, to the people we are friends with. Subsequently, one of the most prevalent questions in most social science literature is: How long has Globalization been around? By examining literature on multiple sides of the globalization discourse, specifically new evidence from social scientists examining greater arrays of early traded commodities, this paper will further the argument that economic globalization began in the early $16^{\text {th }}$ century with the birth and expansion of inter-continental trade between the New World, Asia, and Europe. At the same time, this paper will refute the opposing arguments against this theory and the opposing theory that Globalization has only really began in the early $20^{\text {th }}$ century.
\end{abstract}

Keywords: globalization, commodity price convergence, early globalization, early modern trade, global trade disruption

\section{Introduction}

Throughout recorded human history there have been small shifts in how humans have interacted with each other. The ancient empires of the Far East, Near East, and Europe emerged from the city and city-states. The most recent of these event thresholds is Globalization. Globalization is here, for our benefit or loss, and has begun to affect every part of our society: from the goods we consume, to the money we use, to the music we listen to, to the people we are friends with. Subsequently, one of the most prevalent questions in most social science literature is: How long has Globalization been around? By examining literature on multiple sides of the globalization discourse, this paper will further the argument that economic globalization began in the early $16^{\text {th }}$ century with the birth and expansion of inter-continental trade between the New World, Asia, and Europe.

\section{What is Globalization?}

A parsimonious approach suggests defining the scope of exploration by using the above question regarding globalization. To answer, "What is Globalization?" this paper shall focus on economic 
globalization, which will concern trade, currency, finance, exchange, markets, and other related ideas. It will not consider culture, non-trade diplomacy, and any type of anthropological (noneconomic/finance) investigations of globalization. Although these other facets of social science are concerned with globalization, an exploration of strictly economic globalization serves a specific purpose. Much of the contemporary discussion on Globalization evokes Susan Strange's "Cui Bono?" (who benefits?) (Jones, 2001) in the form of "Who Benefits from Globalization?" However, to quote an article from The Economist magazine, "The answer ... is that it is impossible to say how much of a "good thing" a process is in history without first defining for how long it has been going on." (The Economist, 2013) With the objective and scope of research in mind, the body of literature can now be examined.

\section{Literature Review}

In social science literature regarding globalization a dichotomy has developed. First is the belief that globalization is a phenomenon that has existed for many years and began in the $16^{\text {th }}$ century; this is believed to be a result of the connections in trade developed between the New World, Asia, and Europe. On the other side of this dichotomy is the belief that globalization is a much more recent phenomenon; perhaps beginning in the early $20^{\text {th }}$ century, but fully maturing in the early 1950s, alongside the development of the Bretton Woods Institutions (World Bank 'WTO', International Monetary Fund 'IMF', General Agreement on Tariffs and Trade/World Trade Organization 'GATT/WTO'). While these two periods receive the most attention in the academic community, many other years have been put forth as having touched off globalization, including, "benchmark years such as 1492, 1521, 1571, 1648, 1789, 1848, 1873, 1913, 1929, 1945, or 1973 (McKeown, 2007)."

\section{Contemporary Globalization}

In defense of these two positions, social scientists have written an abundance of literature. However, each bloc has a work which forms the crux of its argument. The first of these is in the vein of what will be known as Contemporary Globalization for the purposes of this paper: works by Kevin H. O'Rourke and Jeffrey G. Williamson (2002), the principal of which is their paper for the National Bureau of Economic Research (NBER) entitled "When Did Globalization Begin?". Through their research, they accomplish two things: 1. They establish a concrete definition of Globalization: commodity price convergence (O'Rourke \& Williamson, 2002), or the mutual convergence of commodity prices due to flow of goods, alongside reduction in tariffs and transport costs (O'Rourke \& Williamson, 1994). 2. Their interpretation and analysis of the data states that the conditions for globalization were "not satisfied during the three centuries following 1492 and 1498, but that they did start being satisfied about two centuries ago. We see no evidence documenting significant pre-19th century global price convergence." Their assertion is that globalization begins with a 'big bang' moment occurring in the 1840s with the repeal of the Corn Laws in Great Britain.

\section{Early Modern Globalization}

The opposing view is represented primarily by the works of Dennis Flynn and Arturo Giraldez (2004), and their very pointed critique of O'Rourke and Williamson. In their work, Flynn and Giraldez (2004) explicitly state that, in their belief, globalization began in 1571; this is the year when trade between the New World, Asia, and Europe was linked via the establishment of the Spanish trade port in Manila (Flynn \& Giraldez, 2004). This theory will be referenced as Early 
Modern Globalization in this paper. The critique of O'Rourke and Williamson is divided into five parts and highlights what they believe are the shortcomings of the former's paper: 1 . The definition of Globalization offered by O'Rourke and Williamson is too narrow, 2. The selective ignorance of the global silver trade that occurred in the $16^{\text {th }}-17^{\text {th }}$ centuries, 3 . The mischaracterization of goods such as silks, tea, and particularly sugar as "luxury goods," 4 \& 5. By defining their conceptualization of globalization so narrowly, O'Rourke and Williamson ignore goods that had little trade value, (namely plants and seeds from the new world); these goods drastically affected population growth, albeit, on a "time-lag basis", two interlinked concepts undervalued in the initial analysis. With these two main branches of research explained, it is important to now examine what can be added to the dialogue through scrutiny of additional sources.

\section{Commentary on the Two Theories}

Upon initial examination, one notices that both main points above, however contemporary, are at least a decade old. Since the initial publication of both sides' seminal works, other social scientists have added their own interpretations, with some falling in one bloc or another. Both sides also received direct critiques in the years following publication. O'Rourke and Williamson's assertion on the fall of transportation costs was attacked by economists finding other reasons for the expansion of grain exports to Europe (Persson, 2004). They were further critiqued for the inability to accommodate other factors considered to have influenced globalization outside of commodity price convergence similar to Flynn and Giraldez, 2004 (Harley, 2000). Academic arguments supporting Contemporary Globalization also arose, buttressed by analyses showing the sustainability of high transaction costs when dealing with trade in Asia. Additional criticisms also latched on to O'Rourke and Williamson's assertions about luxury goods (e.g. sugar and coffee) postulating that although appetites for these goods grew over time, the goods did not drastically affect consumption patterns on the European continent until well after the $18^{\text {th }}$ century (Emmer, 2003). Some works support both parties in this vein by claiming, "What began as an age of globalization - soft and limited, but real - ended as an age of colonialism, something completely different." (de Vries, 2010) Flynn and Giraldez (2004) were criticized for their incomplete understanding of the ramifications of foreign silver in China, with research showing that an analysis of silver in Early-Modern China must be nuanced - both macroeconomically and microeconomically, to grasp its full effects (Deng, 2008). Still other works suggest that within both schools of thought there discrepancies in the definition of Globalization, which carry significant impacts.

\section{A Via Media Refuted}

Throughout the reviews of both works and both opinions there emerges an additional trend regarding the definitions of both "hard" and "soft" globalization. Pursuing a via media between the two largest camps, that of Contemporary and Early Modern Globalization, researchers mete out the distinctions between the two, and hold them both to be relevant and true to an extent. "Hard" Globalization (the definition of commodity price convergence) is found by most scholars to be a phenomenon observed from the $18^{\text {th }}$ century onward. Whereas from the Early Modern camp, the change in the actual flow of goods, the changes in migration and cultural patterns, and the 'imprints' of globalization (i.e. the beginnings of the "time-lags" as mentioned by Flynn and Giraldez, 2004), are labeled as "soft" globalization. In their review of the price dispersion and convergence with regards to grain running up to the $18^{\text {th }}$ century, Dobado-González, GarcíaHiernaux, and Guerrero (2012) offer one such work that highlights both of these facts, alluding to 
the soft/hard definitions (Dobado-Gonzalez et al., 2012). With such a compendium of literature available mentioning the debate, or contributing directly to it, the field of discussion is very robust. However, after reviewing the above literature and other sources, which will be highlighted later, I have come to the following conclusions: 1 . While appreciated by a field of social science desiring much utility and flexibility, the establishment of an additional dichotomy in globalization discourse of "soft" and "hard" definitions only results in the dilution of the earlier debate on when globalization really began, 2 . Despite the seemingly firm and well-founded econometric evidence presented by O'Rourke and Williamson (2004), their examination of certain products and lack of breadth in data examination hinders the effectiveness of said data, leading to 3. Newer data, gathered from the Dutch East India Company's (VOC) historical econometric data and researched by many recent studies, reflects a greater amount of commodity price convergence ( $\mathrm{O}$ 'Rourke and Williamson's own undergirding criterion for globalization's $18^{\text {th }}$ century starting point) occurring earlier, beginning even in the middle and late $16^{\text {th }}$ century. This new data also does not even highlight the missing analysis of silver specie from O'Rourke and Williamson's original article (perhaps due in part to their direct response to Flynn and Giraldez soon after the publication of the latter's work). (O'Rourke \& Williamson, 2004) Thus, the remainder of this work shall examine new evidence that exhibits the Early Modern Globalization theory as holding the greatest water.

\section{New Evidence}

After completing an examination of the other works surrounding the two seminal works above, other data has recently arisen, which sheds more light on price convergence in the early modern period than previously available. This data, unearthed by Dutch social scientists studying early records of the VOC, was analyzed and presented in a Ph.D. thesis and subsequent articles by Klaus Rönnbäck.

\section{Rönnbäck's Data Analysis}

Rönnbäck presents the data analysis in his six-part Ph.D. thesis, which outlines the various ways in which colonialism and trade expanded in the Atlantic economy, beginning in the early $16^{\text {th }}$ century. His work begins by setting the stage for his data. He first conveys that O'Rourke and Williamson have analyzed similar data but have made the following oversights: 1 . O'Rourke and Williamson analyzed too few commodities, if their only criterion for globalization was to be commodity price convergence (Rönnbäck, 2009). 2. Most authors debating globalization on the criterion of commodity price convergence do not specify exactly how long-term such a convergence need occur to be considered invoking globalization; Rönnbäck establishes that 50 years of convergence is to be considered 'long-term'. 3. Although many authors, including O'Rourke and Williamson, address World War I as a major convergence-destroying factor, they do not highlight the French Revolutionary/Napoleonic Wars (cited by Rönnbäck as being between 1793-1815) as having a similar effect (in some works because the occurrence of convergence in this time period is dismissed); Rönnbäck establishes these wars as very distinctly interrupting what could have developed as a continuous period of convergence. 4 . In perhaps the most concrete challenge to O'Rourke and Williamson, Rönnbäck uses a different mathematical measure of convergence, the standard deviation of prices (which he mathematically deflates to accommodate short term overall price falls, resultantly not illustrating actual price convergence), as opposed to the coefficient of variation (which depends too much on ceteris paribus conditions to adequately illustrate convergence, in Rönnbäck's view). It is to be understood from Rönnbäck's analysis that coefficient of variation statistically is unable to accommodate economic phenomena that were 
common in the Early Modern era. For example, using the coefficient of variation to measure convergence could result in the mistaken recognition of globalization during a period of overall price increase as a result of large increases in supply or demand (such as a positive demand shock). Additionally, an ad valorem tariff system did not take into account changes in price that could happen over time, thus calculating convergence using anything that takes merchant profit into account could be both mathematically and historically misleading (Rönnbäck, 2009). These arguments are laid out even before Rönnbäck explores the data collected on commodity prices recently discovered.

\section{Enhancing the Data With More Products}

In order to adequately measure globalization in their original paper O'Rourke and Williamson used four products: textiles, cloves, coffee, and pepper. For Asia, Rönnbäck uses this data, supplemented by European broadcloth and tea. He then adds 5 products traded across the Atlantic: sugar, tobacco, cacao, rum, and slaves. Using the data gathered, Rönnbäck illustrates that adding these other products yields definitive proof of convergence during the late $17^{\text {th }}$ and early $18^{\text {th }}$ century (Many having statistically significant periods of convergence using either measure, coefficient of variation or standard deviation; - standard deviation resulting in firmer findings with a greater array of products.). Returning to analysis of the disastrous effect of wars on convergence, Rönnbäck tempers this analysis by saying,

The largest shock of them all during the period of this paper, having effects upon virtually all of the trade routes included, was the French Revolutionary and Napoleonic wars. Many of the commodities traded did however experience divergence even a short time prior to the French revolution. The empirical evidence in this paper points towards that it was around the time of the American Revolutionary wars (during the late 1770s and 1780s) that a long period of divergence in prices started.

Thus, Rönnbäck, supported by newer data and buttressed by other authors analyzing newer data sets and alternative mathematical approaches, illustrates with certainty that Early Modern Globalization is, indeed, correct in its assumptions. Yet, even with the data explored by Rönnbäck, Early Modern Globalization is supported, although tangentially, by one of its biggest critics Kevin O'Rourke.

\section{An Unlikely Supporter}

In a 2006 paper, O'Rourke wrote extensively on the conditions regarding world trade during the era of the American Revolutionary and Napoleonic Wars. O'Rourke explores the possibility that these wars severely disrupted world trade and resulted in a collapse of worldwide trade volumes, mostly as a result of Napoleon's "Continental System" and Jefferson's Embargo against the combatant nations (O'Rourke, 2006). In a sense O'Rourke is proving Rönnbäck's argument in this work. In their original work, O'Rourke and Williamson do not factor World War I into their calculations on commodity price convergence, at their insistence that such a turbulent event fundamentally altered the area of world trade at the time of incidence. Rönnbäck levels this critique: Why do O'Rourke and Williamson treat these Napoleonic Wars differently from World War I? This glaring hole in the analysis is a significant blemish on the validity of O'Rourke and Williamson's defense of Contemporary Globalization. Moreover, should other wars, which had far reaching effects on either Continental Europe, Asia, or the New World be factored into the 
discussion regarding the beginnings of globalization? With detailed analysis and further scrutiny, O'Rourke and Williamson's assertions that globalization is a purely modern phenomenon fails to hold water.

\section{Conclusion}

This paper began with a simple question: How new are the distinctive features of economic globalization? What began as a simple question developed into a complicated search for an answer. This search revealed that discussions around globalization's beginnings centered around two distinct but opposed arguments. The first of these was the assertion made by O'Rourke and Williamson (the theory of Contemporary Globalization) positing the beginnings of globalization in the early $19^{\text {th }}$ century. In opposition, Flynn and Giraldez propose that Early Modern Globalization, the theory that globalization's roots are concretely tied to the late $16^{\text {th }}$ and early $17^{\text {th }}$ century, holds greater validity. Both groups of social scientists make their case and then publish additional writings reinforcing their own arguments, with little room for agreement. Flynn and Giraldez repeatedly point to silver commodity prices and attack O'Rourke and Williamson's thin definition of globalization. O'Rourke and Williamson assert that their analysis is superior due to its mathematical nature and its irrefutability based on statistical data. Then, in 2009, Klas Rönnbäck wades into the debate, aiming to test O'Rourke and Williamson's theory based on its face value (i.e. the statistical/mathematical underpinnings of their argument). Rönnbäck's fresh attempt to pinpoint globalization's humble beginnings ends up forming a powerful rebuke of O'Rourke and Williamson. Rönnbäck not only claims that the mathematical/statistical approach used by O'Rourke and Williamson is flawed, but also shows that by adding additional commodities to consideration of commodity price convergence illustrates such a phenomenon happening in the very era that O'Rourke and Williamson claim it doesn't. Furthermore, Rönnbäck's analysis highlights the paradox of excluding WWI from data sets without considering other wars, which involve a majority of the world's trading nations. Reviewing O'Rourke and Williamson's assertions in light of Rönnbäck's new approach allows one to conclude that Contemporary Globalization and its theories are invalid. Clearly, Flynn and Giraldez's original assertion that Early Modern Globalization is the correct theory and that Globalization distinctly began in the late $16^{\text {th }}$ and early $17^{\text {th }}$ century passes the greatest muster.

\section{Where to Go From Here?}

Now that the supremacy of the Early Modern Globalization theory has been established, it is important to ponder the ramifications of such a scholarly clarification. Although drawn from O'Rourke and Williamson's critiques of Early Modern Globalization, it is important to recognize that the "implications for world history are, we think, revisionist and profound" With the assertion that globalization began quite early, what can we learn from the history of globalization's first period? It is apparent that globalization was interrupted numerous times, namely by one of two things: disastrous wars on the European continent (although economic historians have perhaps not examined the significance of Near, East, and South East Asian conflicts that are of similar scale if not in amounts of trade interrupted, then in loss of human capital), and mercantilist trading policies that favored closed internal trade from home to mother country. Although not a fullfledged factor, the commodities that Rönnbäck found to have not converged appeared most often to be those products which were traded by companies with absolute or relative monopoly status. Although monopolies are mostly illegal or strongly frowned upon in the modern world, it is the responsibility of civic leaders and historians to alert us all that powerful monopolies did not just 
exist in the distant past, but lived on into the early $20^{\text {th }}$ century, particularly in oil, gas, and precious gems, with their recent specter haunting even the present day with possible resurgence in new and powerful industries.

If globalization has indeed been going on since the $16^{\text {th }}$ century, as this paper and others have now confidently asserted, then the velocity of globalization can be looked at over time. Any quick examination will show that globalization has proceeded more quickly in modern times than ever before. For those who wish to cease or decelerate globalization should realize that the phenomenon has never before marched ahead with the lightning speed that it does today. Stopping it, for those who wish to do so, will not be an easy task, and cannot be done in any foreseeable manner without invoking far-reaching trade embargoes or embroiling most of the trading world into disastrous war.

\section{Globalization: A Concept En Vogue}

Last, but certainly not least, globalization has arisen as a much talked about concept, both in academia and in everyday conversation. Students discuss it in classrooms, parents hear about it on $\mathrm{TV}$, and professors try to include it in every new syllabus published. The globe has entered an era where globalization is a widely recognized and discussed phenomenon. As the concept expands in notoriety, the ways in which globalization is examined, defined, and discussed will evolve. The works dealt with in this paper offer a very finite view of globalization, dealing in a limited fashion with economics and economic history. Globalization, with its ever-increasing speed, will begin to encompass more subjects, be discussed by more people, and be researched via different lenses. As this concept expands, it is important that many voices, like those reviewed in this paper, weigh in on these debates, as this allows for a broader analysis of facts that can help those involved construct a better picture of what the past looked like. The more we can discover about the past, the more we can learn about the present. The more we learn about the present, the more we can predict about the future. Only decades from now will we know how globalization has affected our economies and our lives, thus we should do our best to learn as much as we can, and to better equip ourselves to deal with the inconceivable future that lies ahead.

\section{References}

De Vries, J. (2010). The limits of globalization in the early modern world. The Economic History Review, 63(3), $710-733$.

Deng, K. G. (2008). Miracle or mirage? Foreign silver, China's economy and globalization from the sixteenth to the nineteenth centuries. Pacific Economic Review, 13(3), 320-358.

Dobado-González, R., García-Hiernaux, A., \& Guerrero, D. E. (2012). The integration of grain markets in the eighteenth century: early rise of globalization in the west. The Journal of Economic History, 72(3), 671707.

Emmer, P. (2003). The myth of early globalization: The Atlantic economy, 1500-1800. European Review, 11(1), $37-47$.

Flynn, D. O., \& Giráldez, A. (2004). Path dependence, time lags and the birth of globalisation: A critique of O'Rourke and Williamson. European Review of Economic History, 8(1), 81-108.

Harley, C. K. (2000). A review of O'Rourke and Williamson's globalization and history: The evolution of a nineteenth century Atlantic economy. Journal of Economic Literature, 38(4), 926-935.

Jones, R. (2001). Routledge Encyclopedia of International Political Economy. London, UK: Routledge.

McKeown, A. (2007). Periodizing globalization. History Workshop Journal, 63(1), 218-230.

O'Rourke, K. H. (2006). The worldwide economic impact of the French Revolutionary and Napoleonic Wars, 17931815. Journal of Global History, 1(1), 123-149.

O'Rourke, K. H., \& Williamson, J. G. (1994). Late nineteenth-century Anglo-American factor-price convergence: Were Heckscher and Ohlin right? Journal of Economic History, 54(4), 892-916. 
O'Rourke, K. H., \& Williamson, J. G. (2002). When did globalisation begin? European Review of Economic History, 6(1), 23-50.

O'Rourke, K. H., \& Williamson, J. G. (2004). Once more: When did globalisation begin? European Review of Economic History, 8(1), 109-117.

Persson, K. G. (2004). Mind the gap! Transport costs and price convergence in the nineteenth century Atlantic economy. European Review of Economic History, 8(2), 125-147.

Rönnbäck, K. (2009a). Commerce and colonisation: Studies of early modern merchant capitalism in the Atlantic economy. Gothenburg, Sweden: Department of Economic History, School of Business, Economics and Law, University of Gothenburg

Rönnbäck, K. (2009a). Integration of global commodity markets in the early modern era. European Review of Economic History, 13(1), 95-120.

The Economist. (2013). When did globalisation start? Retrieved from https://www.economist.com/freeexchange/2013/09/23/when-did-globalisation-start 